\title{
顎関節突起骨折の遠隔成績について $\mathbf{X}$ 線写真上での治療状態と臨床予後
}

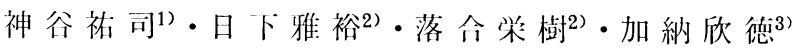

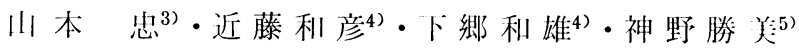

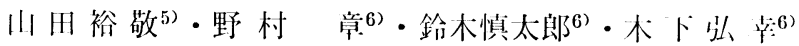 \\ 小牧完 - ${ }^{6)}$ ・河合 幹6)
}

\section{Follow-up studies of 142 cases of unilateral mandibular condylar neck fracture Morphological Change and Clinical Prognosis}

\author{
Yuji KamiYa ${ }^{1)}$ - Masahiro Hinoshita ${ }^{2)}$ - Shigeki Ochiai ${ }^{2)}$ \\ Yoshinori $\mathrm{KanOH}^{3)}$ - Tadashi Yamamoto ${ }^{3)}$ - Kazuhiko Kondor ${ }^{4)}$ \\ Kazuo Shimozato ${ }^{4)}$ - Katsumi JinNo ${ }^{5)}$ - Yutaka Yamad ${ }^{5)}$ \\ Akira Nomura ${ }^{6)} \cdot$ Shintaro Suzuki ${ }^{6)} \cdot$ Hiroyuki Kinosuita ${ }^{6)}$
}

Kanji $\operatorname{Komaki}^{6)} \cdot$ Tsuyoshi Kawai ${ }^{6)}$

\begin{abstract}
Surgical and non-surgical, these two treatments of condylar neck fracture have long been a matter of controversy. The purpose of this paper is to evaluate the prognosis of the condylar neck fractures which were treated by each way. We recalled the patients of the condylar neck fracture to our clinics from a starting period of 6 months after initial treatment. Out of 187 cases we recalled, 142 cases were unilateral and 45 cases were bilateral. We evaluated unilateral cases. Out of 142, 89 were treated non-surgically and 53 surgically.

We classified the fracture levels and conditions by the radiograms and compared those with the clinical prognosis and morphological results.

The results were as follows.

1. Regarding morphological results on the condition of dislocated or disarticulated fracture of TMJ, the surgical group was better than the non-surgical group.
\end{abstract}

1) 姫路赤十字病院溇科口腔外科

（主任：神谷祐司部長）

2) 稲沢南民病院粎科口腔外科

（主任：日下雅裕部長）

3) 豊橋甫民病院歯科口腔外科

（主任：山本 忠部長）

4) 名古屋第一赤十字病院粦科口腔外科 （主任：下鄉和雄部長）

5) 市立岡崎病院齿科口腔外科 (主任：山田裕敬部長)

6) 愛知学院大学菻学部第 2 口腔外科学教室 （主任：河合 幹教授）

1) The Department of Oral and Maxillo-Facial Surgery, Himeji Red Cross Hospital (Chief: Yuji Kamiya)

2) The Department of Oral and Maxillo-Facial
Surgery, Inazawa City Hospital (Chief: Masahiro Hinoshita)

3) The Department of Oral and Maxillo-Facial Surgery, Toyohashi City Hospital(Chief: Tadashi Yamamoto)

4) The Department of Oral and Maxillo-Facial Surgery, Nagoya First Red Cross Hospital (Chief: Kazuo Shimozato)

5) The Department of Oral and Maxillo-Facial Surgery, Okazaki City Hospital (Chief: Yutaka Yamada)

6) The Second Department of Oral and MaxilloFacial Surgery, School of Dentistry, AichiGakuin University(Chief: Prof. Tsuyoshi Kawai) 受付日：平成 4 年 1 月 24 日 
2. The case with better morphological results showed less deviation and pain on TMJ.

3. In the surgical group, Kirschner-wire pinning showed the best morphological result.

Key words: unilateral condylar neck fracture (片側性顎関節突起骨折), morphological change (形態”学的治撩), clinical prognosis（臨床予後）

緒

\section{言}

䪽関節突起尙折は，下嚬省岌折のなかでも頻度の高い 宜折であるが，その治燎法は古くより議論があり意見が 別れている。

治療法には大きく分けて観血的治療法と非観血的治㙩 法に分かれるが，近年の医療技術の進步に伴い観血的治 療法を行ら施設も増加している。しかしながら, 保存的 治療法の利点も捨て難く, 治療法の適応にしばしば悩も ことも多い.

治療法を評㑛するには，臨休に拈けるさまざまな因子 を総合的に統一された基準で詊価することが望ましい が，基準の設㳬，条件の設走など難しい点も多い.

われわれはこれまで独自の基準を設けて詊体を行い， その予後についての詊伹を行ってきた ${ }^{1,2)}$. そのなかで, 形態学的な治揄状態と臨休的な予後とが必ずしも一致し ないことに気づいた。これは，臨休予後の詊価基準に問 題があるのかもしれないと考え, 形態学的な治喻状態 と, 臨休的な予後のうち比較的重要と思われる開日量, 疼痛, 雑音, 開山時の偏位量の四係について調査し, 形 態学的治癒がいかに臨休予後に影響するかについて調べ てみた。

\section{研 究 方 法}

\section{1. 調査対象}

調査対象症例は1982年から1989年の8 年間に, 愛知学 院大学歯学部第 2 1腔外科扣よびその関連18施設を受診 した顎関節突起狊折患者である。これらのらちで初診時 のX線宁真が揃っており，術後 6 か月以上を経過した時 点でリュールし経過観察を行いえた 187 症例中, 臨床子 後の甜体が難しい再側性顎関節突起省折45例を除いた片 側性顎関節突起患者142例を本研究の対象とした。

\section{2. 調査方法}

初診時の外来㟝療録および入院診療録, X線写真から 骨折部位，および状態，処置方法を調査した。

リコール時には調査表にのっとり, 開口量, 開口時の 左右への偏位量, 顎関節の運動時の疼痛, 雑音について 直接患者から所見を得た。 また，予後調查のための $\mathrm{X}$ 線 写真は最低 2 方向から顎関節を撮影した。
重 烈!

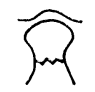

転 位

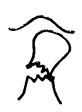

侮传脱行

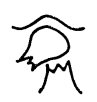

転位脱白

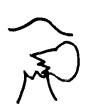

図 1 X線写真による骨折の状態

表 $1 \mathrm{X}$ 線写真けでの治塖状態の分類
完全治㽷

不完全治㨬

変形治㨀
健側と同様，もしくは健常人の顎関節 の形態を保っているもの.

顎関節の形態が多少変形しているもの, もしくは多少の偏位䍩合をきたしたも の.

顎関節の形態が著しく変形しているも の, もしくは偏位脱臼㹩合をきたした ๒の.

\section{研 究 結 果}

\section{1. 骨折状態と形態学的治瘾状態}

片側性顎関節突起骨折 142 症例の骨折状態を, Maclennan の分類 ${ }^{3)}$ を基本にした久保ら ${ }^{4)}$ の分類により，亀 裂骨折，偏位骨折，転位骨折，偏位脱臼骨折，転位脱臼 骨折の 5 種類に分類した（図1）.

また,リュール時のX線写真を 3 人の口腔外科医が読 影を行い，健側の下顩関節突起の形態にほぼ等しいもの を完全治癒, 多少の変形のあるものを不完全治癒, 大き く変形したものを変形治癒として，3段階に分類した (表 1). 
表 2 形態学的変化

\begin{tabular}{|c|c|c|c|c|c|c|}
\hline & \multicolumn{3}{|c|}{$\begin{array}{c}\text { 非観血的处置群 } \\
(89)\end{array}$} & \multicolumn{3}{|c|}{$\begin{array}{c}\text { 観血的処置群 } \\
\text { (53) }\end{array}$} \\
\hline & 完全 & 不完全 & 変形 & 完全 & 不完全 & 変形 \\
\hline 亀裂骨折 & 23 & 0 & 2 & 5 & 0 & 0 \\
\hline 偏位骨折 & 10 & 2 & 0 & 1 & 4 & 0 \\
\hline 転位骨折 & 1 & 4 & 1 & 9 & 4 & 0 \\
\hline 偏位脱臼骨折 & 1 & 1 & 4 & 4 & 2 & 2 \\
\hline 転位脱臼骨折 & 0 & 2 & 38 & 11 & 4 & 7 \\
\hline
\end{tabular}

表 3 関節雑音

\begin{tabular}{l|c|c}
\hline & 女 り & な \\
\hline 完全治療 & 16 & 49 \\
不完全治痔 & 10 & 13 \\
変形治癒 & 22 & 32 \\
\hline
\end{tabular}

表 4 関節疼痛

\begin{tabular}{|c|c|c|}
\hline & あ り & な し \\
\hline 完全治烘 & 7 & 58 \\
\hline 不完全治療 & 5 & 18 \\
\hline 変形治塽 & 19 & 35 \\
\hline
\end{tabular}

142症例のうち, 非観血的治療法を行ったのは 89 例, 観血的治療法を行ったものは53例であった。それぞれの 骨折状態と形態学的治癒状態を, 観血的処置と非観血的 処置に分けて示した（表 2).

その結果，亀裂骨折では非観血的処置群の症例でわず かに変形治瘉をきたしているものの，お扎もね形態学的 治癒状態に問題はなかった。偏位骨折では，観血的処置 群の $80 \%$, 非観血的処置群の $12 \%$ が不完全治癒を呈して いたが，変形治癒をきたしていたものはなかった。転位 骨折においては非観血的処置群で 6 例中 1 例 (17\%) に 変形治癒を残し，完全治癒を得られたものも 1 例 $(17 \%)$ と少なく，観血的処㯰群との間にやや差を認めた，偏位 脱臼骨折では，変形治瘉の占める割合が非観血的処置群 で 6 例中 4 例 $(66 \%)$, 観血的処置群 で 8 例中 2 例 $(25$ \%)であった。さらに転位脱臼骨折では，非観血的処置 群で変形治癒の示寸割合は 40例中 38例 $(95 \%)$, 不完全 治癒は 2 例 $(5 \%)$ で完全治癒は 1 例もなかった。これに 対し観血的処置群では，変形治瘉が22例中 7 例 (32\%) で不完全治瘉が 4 例 (18\%)，完全治癒が 11 例 (50\%) を占め, 非観血的処置群との差を認めた（図 2 ).

\section{2. 形態学的治癒状態と臨床予後}

形態学的治瘉状態がいかに臨床予後に影響しているか を調べるため, 予後調査表から運動時の 関節雑音の有

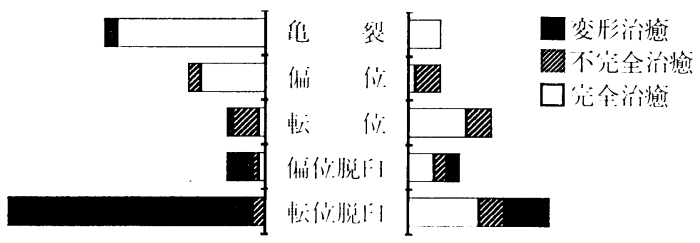

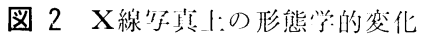

表 5 阔口畹の顎偏位量

\begin{tabular}{|c|c|c|c|}
\hline & $\begin{array}{c}\text { 小 } \\
0 \sim 2 \mathrm{~mm}\end{array}$ & $\begin{array}{c}\text { 中 } \\
3 \sim 5 \mathrm{~mm}\end{array}$ & $6 \stackrel{\text { 大 }}{6} \sim$ \\
\hline 先全治拯 & 48 & 13 & 1 \\
\hline 不完全治獠 & 10 & 8 & 0 \\
\hline 変形治㺊 & 22 & 16 & 13 \\
\hline
\end{tabular}

表 6 最大開口量

\begin{tabular}{|c|c|c|c|}
\hline & $\begin{array}{c}\text { 小 } \\
\sim 29 \mathrm{~mm}\end{array}$ & $\begin{array}{c}\text { 中 } \\
30 \sim 39 \mathrm{~mm}\end{array}$ & $40 \mathrm{~mm} \sim$ \\
\hline 完金治狡 & 3 & 12 & 49 \\
\hline 不完企治痖 & 1 & 4 & 18 \\
\hline 离形治痖 & 3 & 18 & 33 \\
\hline
\end{tabular}

無, 疼痛の有無, 開口時の顎偏位量, 最大開口量を調査 し，個々に比較検討してみた.

\section{1) 関節雑音}

顎運動時に関節雑音を涊めたものは, 完全治瘉で65例 中16例 $(25 \%)$, 不完全治癒で23例中10例 $(43 \%)$, 変形 治瘉で54例中22例 $(40 \%)$ であった（表了）。すなわち, 変形の少ないもの汪ど雑部が少ない傾问にあった。

2) 顎関節の疼痛

顎運動時に顎関節に疼痛を感じた症例は, 完全治癒で 65 例中 7 例 $(11 \%)$, 不完全治瘉で23例中 5 例 $(22 \%)$, 変形治癐で 54例中 19例（35\%）であった（表 4).才な わち，変形の少ないものほど疼痛の出現が少なかった。

3) 開口時の顎偏位量

開口時に拈ける顎の左在への偏位量を 0 〜 $2 \mathrm{~mm}$ を小, 3〜 $5 \mathrm{~mm}$ を中, $6 \mathrm{~mm}$ 以上を大とし 3 段階に分類した. なお, 記載不備の11例は除外した. 完全治癒では, 偏位 が小のものが 62 例中 48 例 $(77 \%)$, 中が 13 例 (21\%), 大

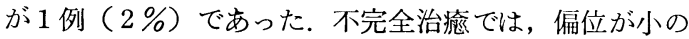
ものが18例中 10 例 $(56 \%)$, 中が 8 例 $(44 \%)$, 大が 0 例 であった。 また，変形治搭では，偏位が小のものが51例 中22例 $(43 \%)$, 中が16例 $(31 \%)$, 大が14例 $(26 \%)$ で あった（表 5 ）.

すなわち, 変形の程度の大きいものほど開口時の顎の 
表 7 手術方法別の形態学的治瘾状態

\begin{tabular}{|c|c|c|c|}
\hline 手術片法 ( $\mathrm{n}$ ) & 完全治癒 & 不完全治癒 & 変形治瘾 \\
\hline キルシュナー (24) & 17 & 6 & 1 \\
\hline ワイヤー & 7 & 6 & 3 \\
\hline プレート & 4 & 1 & 3 \\
\hline スクリュ & 0 & 1 & 1 \\
\hline その他 & 2 & 0 & 1 \\
\hline
\end{tabular}

表 8 非観血的処置群における形態学的治療状態と 骨折部位

\begin{tabular}{l|c|c|c}
\hline 上 部 (34) & 完全治療 & 不完全治㽷 & 変形治療 \\
\hline 亀裂骨折 & 21 & 0 & 0 \\
偏位骨折 & 4 & 1 & 0 \\
転位骨折 & 0 & 2 & 0 \\
偏位脱臼骨折 & 0 & 0 & 3 \\
転位脱曰骨折 & 0 & 1 & 2 \\
\hline
\end{tabular}

\begin{tabular}{l|c|c|c}
\hline 中 部 (25) & 完全治痖 & 不完全治療 & 変形治瘾 \\
\hline 亀裂骨折 & 2 & 0 & 0 \\
偏位骨折 & 4 & 1 & 0 \\
転位骨折 & 0 & 0 & 0 \\
偏位脱臼骨折 & 1 & 1 & 1 \\
転位脱臼骨折 & 0 & 1 & 14 \\
\hline
\end{tabular}

\begin{tabular}{l|c|c|c}
\hline 下 部 (30) & 完全治癒 & 不完全治癒 & 変形治瘾 \\
\hline 亀裂骨折 & 0 & 0 & 3 \\
偏位骨折 & 2 & 0 & 0 \\
転位骨折 & 1 & 2 & 1 \\
偏位脱臼骨折 & 0 & 0 & 0 \\
転位脱臼骨折 & 0 & 0 & 21 \\
\hline
\end{tabular}

偏位は大きかった，特に変形治瘉において，6 $\mathrm{mm}$ 以上 の偏位をするものが $26 \%$ を占めていることは特記するも のがある。

\section{4) 最大開口量}

最大開口量を，29 mm 以下を小，30〜39 mm を中, $40 \mathrm{~mm}$ 以上を大とし 3 段階に 分類した. 1 例は記載不 備のため除外している。 その結果, 完全治癒では64例中 3 例 (5\%) が小, 12 例 (18\%) が中， 49 例 (77\%) が 大であった。不完全治癒では，23例中 1 例 (4\%) が小， 4 例 (17\%) が中, 18 例 $(78 \%)$ が大であった。一方, 変形治瘉では 54例中 3 例 $(6 \%)$ が小で, 18 例 $(33 \%)$ が中，33例 $(61 \%)$ が大であった（表 6 ).

すなわち, 変形の程度が大きいとやや開口量が少なく なるといら傾向がみられた。

5 ）手術方法と形態学的治癒状態

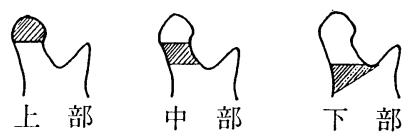

図 3 骨折部位の分類

観血的治療法53例に行われていた固定方法は，キルシ ュナー24例, ワイヤー16例, プレート 8 例, スクリュー 2 例, その他 3 例であった. それぞれの固定方法別の形 態学的治癒状態をみてみると, キルシュナーが 24 例中 17 例 $(71 \%)$ の完全治瘉を得て扣り比較的良好な結果を得 ていた，それ以外では，ワイヤーが16例中 7 例 (44\%)， プレートが 8 例中 4 例 $(50 \%)$ の完全治癒で, 変形治瘉 の占める割合が多かった（表 7).

6 ) 非観血的処置群の骨折部位, 状態と形態学的治瘉 状態

非観血的処置群89例について，その骨折部位を下部， 中部, 上部の 3 段階に 分け (図 3), 骨折状態とともに 形態学的治瘉状態を観察した（表 8 ）.

その結果, 変形治瘉が多かったのは, 中部, 下部の転 位脱臼骨折であった。

\section{考察}

顎関節突起骨折は，下顎骨折のなかでも正中部，下顎 角部とともに発生頻度の高い骨折で，その頻度は下顎骨 折の $29.3 \%$ に上るといわれている5). 近年交通事情が 発達して扣り, 交通事故による下顎骨折はより複雑にな って，関節突起の骨折も併発しているケースもよく見か けるようになった。顎顔面外傷を扱ら口腔外科の日常臨 床のなかでも，比較的扱ら頻度の高い疾患であるが，そ の治療方法は施設によって違いが大きい.

顎関節突起骨折の治療法には, 大きく分けて観血的治 療法と非観血的治療法があり, 古くから非観血的治療法 が推奖されてきた ${ }^{3)}$. しかしながら，近年の医療技術， 器械の発達は目覚ましく, 観血的治療法も適応されるよ らになり，その手術方法も確立されてきた ${ }^{6 \sim 11)}$. その適 応については, 術者が利点, 欠点を十分熟知していなけ ればならないが, 最も重要な予後成績についての報告は 少ない.

われわれは，この点について過去に顎関節突起骨折の 臨床予後について研究を行ってきた ${ }^{1,2)}$. そこで, 単純に 臨床的予後のみを比較した場合, 非観血的治療法と観血 的治療法に大きな差を認めないこと ${ }^{1)}$, 固定方法によっ ては観血的治療法が優れていることもあることをあきら かにしてきた2)。 その過程のなかで，X線写真上での治 癒状態が必ずしも予後に反映していないこと, 予後判定 には開口量のみでなく, 疼痛, 顎偏位など多くの因子が 


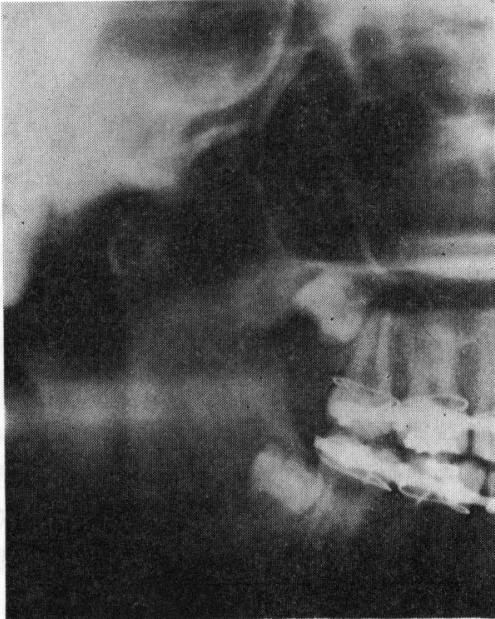

写真 113 歳女性の上部転位脱臼骨折 症例の初診時のX線写真 非観血的治療を行った。

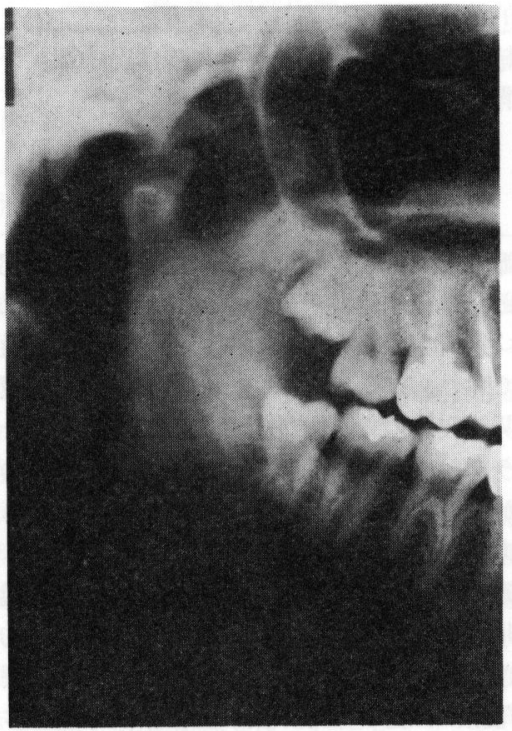

写真 2 写真 1 の 47 か後のX線写真 変形治癒をきたしている。 開口量 $44 \mathrm{~mm}$, 開口時関節疼痛㐫り, 雑音なし，開口時偏位 $0 \mathrm{~mm}$

あり，どの因子に重きを打くかによって予後の判定が変 わってくることなど予後判定基準の設定に疑問が生じて きた。

島原ら ${ }^{12)}$ は, 臨床的, X線的に詳細に予後の検討を行 った結果, 両者には必ずしも相関関係があるとは限らな いと報告している。安田ら ${ }^{13)}$ も同様の結果を得て, 形態 評価については関節頭の形態だけでなく，関節円板を含

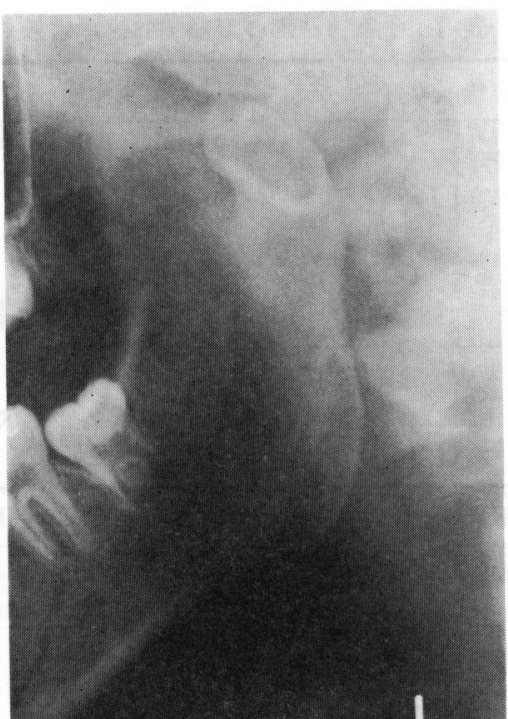

写真 3 16歳男性の中部偏位脱臼骨折 症例の初診時 $\mathrm{X}$ 線写真

非観血的処置を行った。

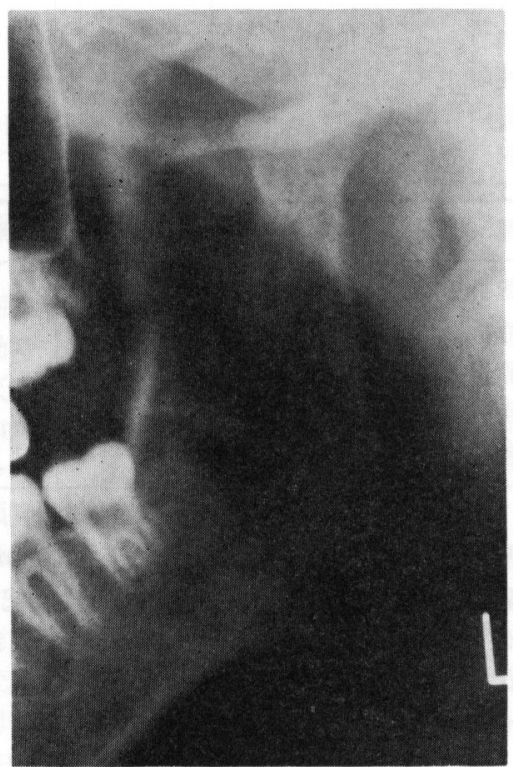

写真 4 写真 3 の 8 か月後のX線写真 変形治癒をきたしている。

開口量 $54 \mathrm{~mm}$, 開口時関節疼痛あり, 雑音なし, 開口時偏位 $5 \mathrm{~mm}$

む顎関節部の解剖学的形態を包括的に評価する必要があ ると述べている.

そこでわれわれは, 形態学的な治瘜状態と臨床予後の それぞれの因子がいかに関わっているかを調査すべく， 


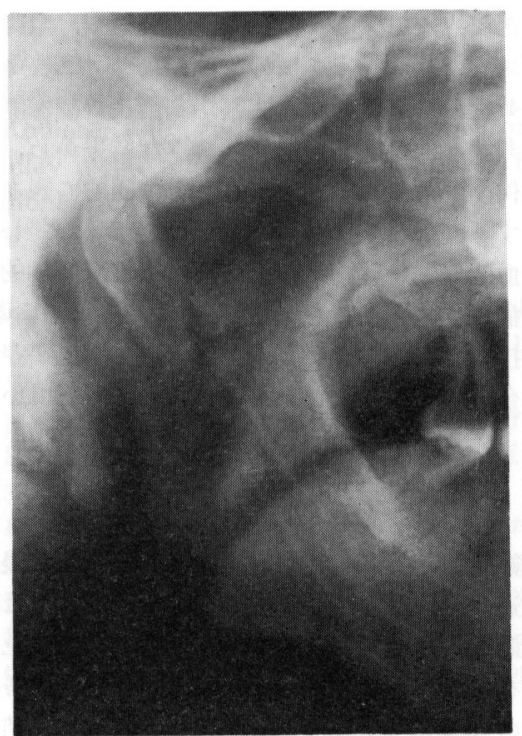

写真 523 歳男性の下部転位骨折症例 の初診時の X線写真

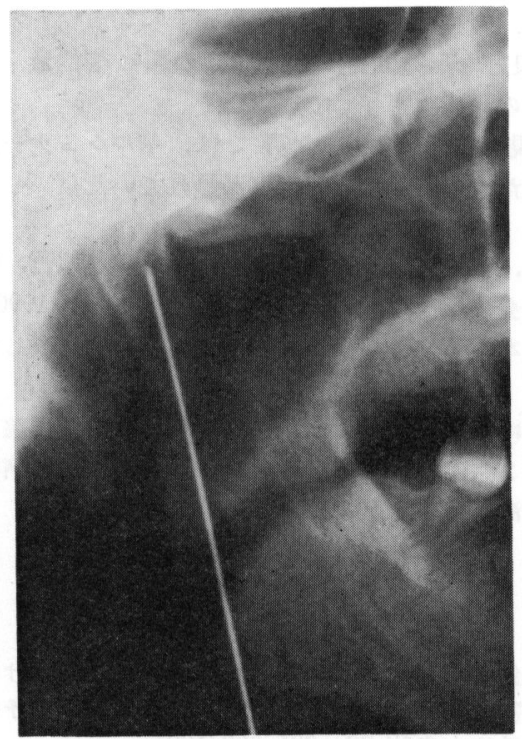

写真 6 キルシュナー鋼線による観血 的処置を行った。

処置前のX線写真とリコール時のX線写真によって骨折 部位, 状態, 形態学的治癒状態と予後について調査研究 を行った。

\section{1. 骨折状態と形態学的治癒状態}

形態学的治瘉状態を観血的処置群と非観血的処置群と に分けて観察してみた. 非観血的処置群では当然の結果 であるが, 骨折状態の程度が重くなるほど形態学的治㾓

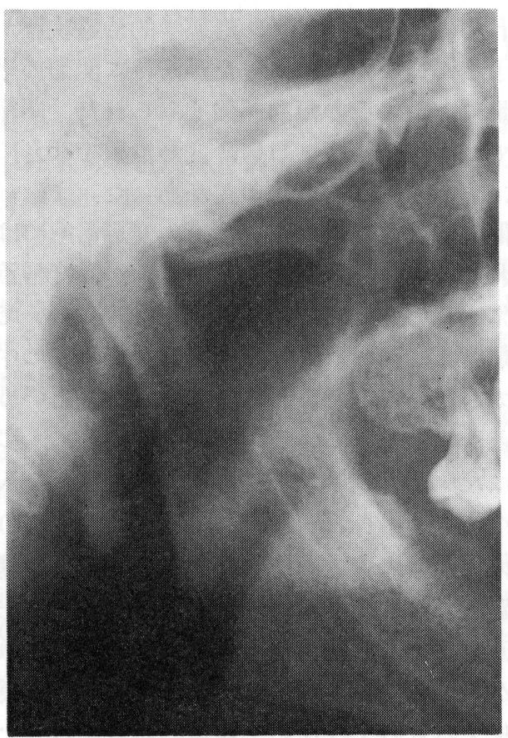

写真 7 写真 5 の 9 か月後のX線写真 完全治癒をきたしている. 開口量 $42 \mathrm{~mm}$, 開口時関節疼痛なし, 雑音なし, 開口時偏位 $2 \mathrm{~mm}$

状態は劣っていた，特に脱臼を伴ら骨折ではそのほとん どが変形治瘉をきたしていた，偏位脱臼骨折で66\%，転 位脱臼骨折で95\%が変形治痊をきたしていた（写真 1〜 4). 非観血的処置群は, 一般的な後療法でいわれている 積極的な開口訓練をほとんどの症例が行っているが, 形 態学的治癒にはなんら貢献をしていないことが分かる。

一方, 観血的処置群では偏位脱臼骨折で $25 \%$, 転位脱 臼骨折で $32 \%$ が変形治瘉をきたしているのみで, 非観血 的処置群との間にあきらかな差を認めた（写真 5〜7).

しかしながら, これらの変形治瘉をさたした症例のほと んどは, 術直後では整復状態が良好であったにもかかわ らず変形をきたしていることから，手術侵襲，固定方 法, 後療法について今後検討を要するものと思われる.

いずれにせよ, 観血的処置群では形態学的な治瘉状態 が非観血的処置群と比較してあさらかに良好であった。 過去の報告では ${ }^{12,13)}$, この形態学的治癒が予後に反映さ れないとのことであるが，われわれは，この点について 観血, 非観血的処置を問わず形態的な治癒状態と臨床予 後について検討を行った。この臨床予後は古くから, 中 富の分類 ${ }^{14)}$ にって検討されてきたが, 臨床予後にも色 々な因子が含まれているので主な因子を取り上け゚て形態 学的治癒状態との関係を調査した.

\section{2. 形態学的治癒状態と臨床予後}

臨床予後の主な因子を, 関節雑音, 関節の運動時の疼 痛, 開口時の顎の偏位量, 最大開口量にしぼり, それぞ れ形態学的治瘉状態との関係を調査した。 
いずれの因子に打いても，形態学的治瘉状態が良いほ ぞその予後が良い傾向にあったが，特に関節の疼痛と顎 の偏位量においてその傾向が強くみられた. 関節の疼痛 に関しては, 完全治瘉で $11 \%$, 変形治瘉で $35 \%$ に疼痛が みられ，その率では約 3 倍の差があった。 また，開口時 の顎の偏位量であるが, 完全治瘉, 変形治癒にはほとん どみられない $6 \mathrm{~mm}$ 以上偏位するものが, 変形治癒にお いて $25 \%$ も認められている。顎の偏位量については, 中 富の分類 ${ }^{14)}$ では含まれておらず，過去の報告の中でも触 れられていないが，われわれは開口時の歪といら審美的 な要素と異常顎運動による歯牙の早期接触にもつながる ものではないかと考えて予後の 1 つの因子に入れてい る.

以上の点から考えると, 顎関節突起骨折の形態的治瘉 状態は臨床予後に関与すると考えられる.すなわち, 良 い形態回復ができれば予後も良くなると考学られる。し かしながら，このことがすぐに観血的処置を推奖するこ とを意味するものではない．観血的処置を行った症例の すべてが形態学的に良好な予後を得られていないからで ある。

観血的処置を行った症例の固定方法別の形態学的治癒 状態をみてみると, キルシュナーが最も良く $71 \%$, ワイ ヤーが $44 \%$ ，プレートが50\%の完全治癒であった。 むち ろん状態が画一でないから一概にはいえないが，この結 果から考劣ればワイヤー, プレートの固定方法は十分満 足の行くものではないといえる. キルシュナーと比較す ると, 剥離の範囲も大きく手術侵襲が大きいこと, ワイ ヤーは固定力からいえば結禁の方法によっては固定力が 十分でないことなどが考えられる，症例数も少なく，他 の優れた手術法もあるので, よりよい予後を得るための 手術法の評価は今後の課題としたい.

非観血的処置を行った群で, 形態学的治瘉の悪かった 部位と状態は, 上部, 中部の転位脱且骨折であった。こ の部位の転位脱臼骨折については，手術によって整復で きても適当な固定方法がなく，小骨片の除去を行う場合 がある，われわれは形態回復が予後を良くするといら考 えから, 関節頭切除術については行っていない. 今後こ の部位の骨折についての治療方法について適当な処置方 法について検索を行っていきたい.

以上述べたごとく, 今回の調查研究の結果から顎関節 突起骨折の予後は, 形態学的な回復と関連があることが 分かった。このことから, 形態学的回復が望めなかった 偏位脱臼骨折, 転位脱臼骨折は観血的処置の適応ともい える。久保ら ${ }^{4)}$ は 124 例の予後観察の報告のなかで, 非 観血的処置施行例のなかで基底部または下頸部の転位脱 臼骨折がきわめて予後不良であったことにより，この骨 折型を観血的処置の適応と考えるにいたったと述べてお り，われわれの考えも医等しいものである。

しかし，観血的処置については利点のみではなく，い
ろいろな欠点を有する。手術瘢痕の問題や, 全身麻酔に 伴らリスク，顔面神経麻痺の危険性などである，上谷 $ら^{15)}$ は49症例の詳細な予後観察から術後の機能障害が観 血的, 非観血的処置ともに同じよらな結果から，観血的 処置に伴らリスクを考慮に入れると積極的に観血的処置 を推奨するにいたらなかったと述べている，われわれ も, 観血的処置を行ったにもかかわらず形態学的回復の 不良な症例もあったことにより, 今後の手術法の改良 ${ }^{16)}$, 手術手技の確立，扣よびその評価を参考に，より適切な 処置を今後も慎重に検討していきたいと考えている.

\section{結語}

顎関節突起骨折の予後を調べるために，処置後 6 か月 以上経過した時点でリコールし，予後観察しえた片側性 の顎関節突起骨折患者 142 例についてX線写真上での治 癒状態を観察した.さらに形態学的治癒状態と各種の臨 床子後の関係についてそれぞれ 調査し以下の結論を得 た.

1. 転位, 偏位脱臼, 転位脱臼骨折では, 観血的処置 群のほうが非観血的処置群より形態的に良好な結果が得 られた。

2. 良好な形態回復は, 開口時の顎の 偏位量, 顎関節 の疼痛の軽減に寄与していた。

3. 観血的処置を行った群では，キルシュナー鋼線を 使用したものが最も形態叮復が優れていた.

なお，本㖮文の要旨は第10回ヨーロッパ頭蓋，顎顔侕 外科学会 (E.A.C.M.F.S.)（於：ベルギー, 1990)，第 35回日本口腔外科学会総会（於：岡山）で発表した。

最後に本研究に多大なご支援を頂いた曼知学院大学楼 学部第 2 口腔外科学教室の医局員, 扣上び関連病院の先 生方に深厚なる謝意を捧げます。

\section{引用 文 献}

1）鈴木慎太郎, 日下雅裕, 他：多施設に扣ける下 顎関節突起骨折症例の臨床統計的観察之予後. 爱院大菌誌 29: 301-308 1991.

2) 神谷鿆司, 日下雅裕, 他: 下顎関節突起骨折に 扣けるキルシュナ一鋼線使用症例の予後につい て. 日口外誌 37: 1165-1172 1991.

3) Maclennan, W.D.: Consideration of 180 cases of typical fractures of the mandibular condylar process. Brit J Plast Surg 5: 122-132 1952.

4) 久保四郎, 村橋濩, 他：顎関節突起骨折 124 症例に関する臨床的検討, 特にその分類につい て。 日外誌 29: 1974-1805 1983.

5) Ellis, E. and El-Attar, A.: Ten years of mandibular fractures: An analysis of 2,137 
cases. Oral Surg 59: 120-129 1985.

6) Thoma, K.H.: Oral Surgery. $5 \mathrm{~cd}$. The C.V. Mosby, Co, Saint Louis, 1969, p 572.

7) Robinson, R. and Yoon, C.: New onlayinlay metal splint for immobilisation of mandibular subcondylar fractures. Amer J Surg 100: 845-852 1960.

8) Stephenson, K.L. and Graham, W.C.: The use of the Kirschner pin in fractures of the condyle. Plast \& Reconstr Surg 10: 19-23 1952.

9）田代英雄，納富一一克：下顎関節突起基部骨折の Kirschner 鋼線による固筀. 形成外科 X XII: 36-42 1979.

10) Petzel, J.R.: Instrumentarium and Technique for Screw-Pin-Osteosynthesis of Condylar Fractures. J Max-Fac Surg 10: 8-13 1982.

11) Kitayama, S.: A New Method of Intra-Oral Open Reduction Using a Screw Applied
Through the Mandibular Crest of Condylar Fractures. J Cranio-Max-Fac Surg 17: 16-23 1989.

12）島原政司，小野克己，他：下顎関節突起骨折に 扣ける非観血的処置例の遠隔成績について。口 科誌 38：406-415 1985.

13）安田保喜, 川上哲司, 他：顎関節突起骨折の臨 床的研究一第 1 報一開設 4 年間の処置と予後に 関する統計的観察。奈医誌 37：523-531 1986.

14）中富憲次郎：顎関節突起骨折の臨休的研究. 口 科誌 13: 132-156 1964.

15）上谷和人，村上賢一郎，他：下顎関節突起骨折 の臨床的研究一第 2 編 49 症例 66 関節の長期遠 隔治療成績。日顎誌 1: 353-362 1989.

16) Choung, R. and Piper, M.A.: Open reduction of condylar fractures of the mandible in conjunction with repair of discal injury. $J$ Oral Maxillofac Surg 46: 257-263 1988. 